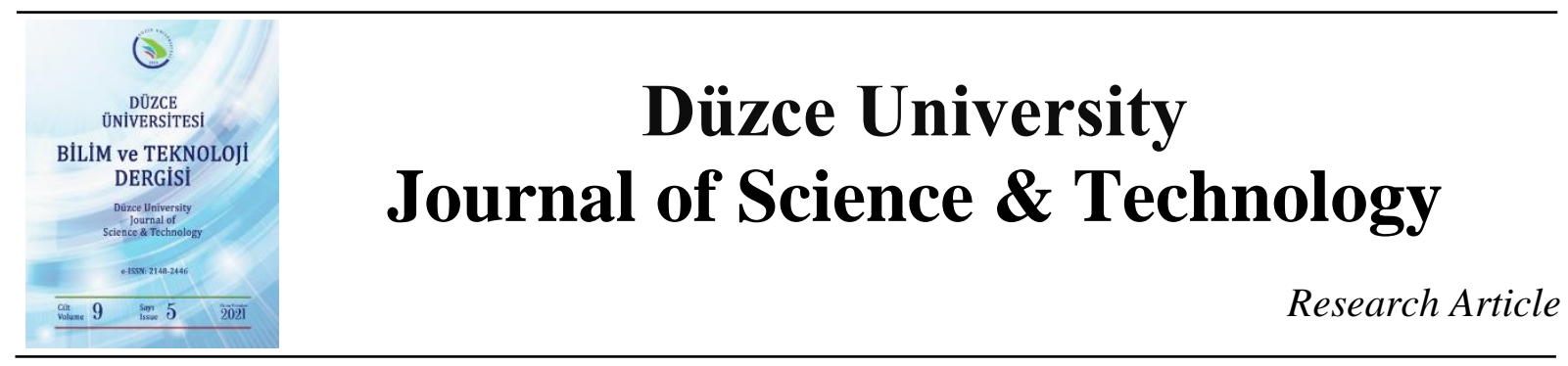

\title{
Ultrasound-Assisted One-Pot Synthesis of 9-(Substituted heteroaryl) acridinedione Derivatives
}

\author{
(iD Duygu BAYRAMOĞLU ${ }^{a}$, (D) Mehtap YAKUT ${ }^{\text {a, * }}$ \\ ${ }^{a}$ Department of Chemistry, Faculty of Science, Ankara University, Ankara, TURKEY \\ * Corresponding author's e-mail address: mehtapyakut@gmail.com
}

DOI: $10.29130 /$ dubited.926881

\begin{abstract}
$\underline{\text { ABSTRACT }}$
An efficient green approach for the synthesis of 9-heteroaryl-acridine-1,8-dione derivatives (3a-f) was accomplished via reactions of dimedone (1) with various heteroaromatic aldehydes (2a-f) and ammonium acetate through one-pot multicomponent reactions in water under mild conditions using ultrasound irradiation in excellent yields. Of the synthesized compounds, 3d-f were novel and this process presents the advantages of high yields and easy work-up procedures. Spectral analyses were accomplished by FTIR, ${ }^{1} \mathrm{H}$ NMR, ${ }^{13} \mathrm{C}$ NMR and LC-MS TOF analyses.
\end{abstract}

Keywords: Multicomponent reactions, Dihydropyridine, Heteroaromatic aldehydes, Dimedone, Ultrasound irridiation.

\section{Ultrases Destekli 9-(Substitue heteroaril) akridindion Türevlerinin Tek Basamakta Sentezi}

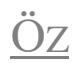

Bu çalışma ile 9-heteroaril akridin-1,8-dion türevlerinin (3a-f) sentezi için yeşil kimya yaklaşımını benimseyen etkili bir yöntem geliştirilmiştir. Dimedon'un (1), çeşitli heteroaromatik aldehitlerle (2a-f) amonyum asetat kullanılarak sulu ortamda ve tek kapta ultrases dalgaları ile reaksiyonları gerçekleştirilmiştir. Bu yöntem ile 1lıman koșullar altında, hedeflenen moleküller yüksek verimle elde edilmiștir. Ayrıca yöntemin kolay uygulanabilir olması ve deney sonrası ișlemlerinin son derece basit olması en önemli çalıșma avantajlarındandır. Sentezlenen bileşiklerden 3d-f orijinal moleküller olup, elde edilen tüm ürünlerin karakterizasyonları FTIR, ${ }^{1} \mathrm{H}$ NMR, ${ }^{13} \mathrm{C}$ NMR ve LC-MS TOF analizleri kullanılarak gerçekleştirilmiştir.

Anahtar Kelimeler: Çok bileşenli reaksiyonlar, Dihidropiridin, Heteroaromatik aldehitler, Dimedon, Ultrases

Received: 23/04/2021, Revised: 07/06/2021, Accepted:16/06/2021 


\section{INTRODUCTION}

Over the last decade, synthetic chemists are interested to develop kind of safer technologies to prevent the growing amounts of waste and toxic side products that consecutively lead to chemical pollution. For this purpose multicomponent reactions (MCRs) have received increasing attention in synthesis to provide establishing newer chemical transformations in a single step using simple, non-toxic, ecofriendly medium and readily available substrates without the isolation of any intermediates [1].

Acridinediones are a significant type of nitrogen-mediated heterocycles found in many complex compounds [2]. Acridine analogous possess a wide broad spectrum of pharmaceutical and biological activities. Among them, 1,8-dioxodecahydroacridines are a leading class of aza-heterocycles in which contain 1,4-dihydropyridine (1,4-DHP) core, which acts as fluorescent probes in bioanalytical chemistry and also used as potential drug candidates for the treatment of cardiovascular diseases [3], DNA intercalators, SIRT1 inhibitors, antitumor, calcium-channel blockers, antileukemic, antifungal, anticancer, anti-atherosclerotic and bronchodilator (Fig. 1.) [4-9]. Some of them are used in dyesensitized solar cells and some are also used as laser dyes, chemosensors, and initiators in the photopolymerization process [10-13].<smiles></smiles>

Cardiovascular Activity Antioxidant Activity<smiles>CCOC(=O)C1=C(C)NC(C)=C(C(=O)OCC)C1c1ccc(Br)s1</smiles>

Calcium-antagonist Antibacterial Activity

Figure 1. Structures of the most known biological active 1,4-dihydropyridine derivatives.

The multicomponent Hantzsch reaction is a prominent process for acridinediones involving thermal condensation reactions of several carbonyl groups and different nitrogen sources like urea, ammonium acetate and ammonium nitrate, etc. [14]. Since then several improved catalysts reported for the synthesis of 1,8-dioxodecahydroacridine derivatives are montmorillonit [15], $\beta$ cyclodextrin monosulphonic acid [16], CuI nanoparticles [17], citric acid/EtOH reflux [18], ionic liquids [19], $\mathrm{Co}\left(\mathrm{NO}_{3}\right)_{2} .6 \mathrm{H}_{2} \mathrm{O}$ [20], $\mathrm{Fe}_{3} \mathrm{O}_{4} @ \mathrm{SiO}_{2}-\mathrm{PEG} / \mathrm{NH}_{2}$ [21], $\mathrm{Fe}_{3} \mathrm{O}_{4} / \mathrm{HT}-\mathrm{SMTU}-\mathrm{ZnII}$ [22], sulphonated sawdust $\left(\mathrm{SD}-\mathrm{OSO}_{3} \mathrm{H}\right)$ [23] in toxic/nontoxic solvents using microwave, ultrasound, reflux, and traditional heating methods [24, 25]. However, these methods have some disadvantages such as requireing expensive catalysts and their recovery and reusability, higher temperature, longer reaction time, cumbersome workup process and also lower yields. Therefore, it is still necessary to develop an environmentally benign, "green" synthetic procedures obtaining acridinediones using cost-effective, non-toxic starting materials, high yields, short reaction time, simple isolation of the product and eco-friendly clean processes. Hence, the use of sonochemical methods in organic synthesis has been evaluated as substantial steps to improve and accelerate the synthetically precious reactions. Ultrasound-assisted 
reactions can be distinguished from the conventional synthetic methods by their potential to serve as an alternative pathway for various chemical reactions and also synthesizing the complex molecules with short reaction times and mild conditions [26-28].

Herein, we focused our attention to report a green protocol with an effective, easily operated, and convenient synthetic method for the synthesis of acridine-1,8- $(2 \mathrm{H}, 5 \mathrm{H})$-dione (3a-f) in water through a one-pot catalyst-free reaction of dimedone (1), heteroaromatic aldehydes (2a-f), and ammonium acetate under ultrasonic irradiation.

\section{EXPERIMENTAL}

\section{A. PHYSICAL MEASUREMENTS AND MATERIALS FOR SYNTHESIS}

Ultrasonication was performed in an Elmasonic S70 H with frequency of 50/60 Hz, 220-240 V and output power of $750 \mathrm{~W}$ and the whole of the reactions were conducted in a sonic bath. Structural identification of the compounds obtained was accomplished by following convenient analytical methods. Infrared spectra were recorded on a Perkin-Elmer Spectrum 100 Series FT-IR spectrometer. The FT-IR spectra were taken by KBr pellets or directly by ATR, in both using the average of 25 scans. ${ }^{1} \mathrm{H}-\mathrm{NMR}$ spectra were obtained with a Varian Mercury-400 High-Performance Digital FT-NMR instrument (Mercury-400BB) and deuterated chloroform was used as solvent. Chemical shifts $(\delta)$ are expressed relative to tetramethylsilane (TMS). HRMS were recorded by LC-MS TOF electrospray ionization technique (Agilent Technologies 6230-A). Melting points (up to $350{ }^{\circ} \mathrm{C}$ ) were determined using an Electrothermal IA9300 digital melting point apparatus and reported uncorrected (Bibby Scientific Limited, OSA, UK). Thin layer chromatography (TLC, Merck, 20×20, Silica Gel 60 F254) was used to monitor the progress of the experiments steadily.

\section{B. GENERAL PROCEDURE FOR THE SYNTHESIS OF ACRIDINE-1,8-(2H,5H)- DIONE DERIVATIVES}

A typical reaction was carried out in a $50 \mathrm{~mL}$ round bottom flask with a condenser, a mixture of aromatic aldehyde $(1 \mathrm{mmol})$, dimedone $(2 \mathrm{mmol})$, ammonium acetate $(1 \mathrm{mmol})$, and water $(8 \mathrm{~mL})$ was added in to the flask and then irradiated to ultrasonication (a frequency of $50 / 60 \mathrm{~Hz}$ and a power of $750 \mathrm{~W}, 6.9$ L) at $70^{\circ} \mathrm{C}$ for about 1 hour. The round bottom flask was placed at the center of the ultrasonic bath and the surface of the reactants in the flasks was placed slightly lower than the water level in the bath. After the completion of the reaction, the mixture was cooled to room temperature, filtered, and washed with $3 \times 10 \mathrm{~mL}$ cold water. The solid products were then collected and purified by recrystallization using abs. ethanol.

\section{B. 1. 3,3,6,6-Tetramethyl-9-(thiophen-2-yl)-3,4,6,7,9,10-hexahydroacridine $1,8-(2 \mathrm{H}, 5 \mathrm{H})$ - dione (3a)}

White solid, yield: $97 \%$, m.p.:302 ${ }^{\circ} \mathrm{C}$ (Lit m.p.:305-307 ${ }^{\circ} \mathrm{C}$ [29]), FT-IR $\left(v_{\max } / \mathrm{cm}^{-1}, \mathrm{KBr}\right): 2954,2871$, 1579, 1449, 1373, 1252, 1168, 1152, 1078, 1059, 868, 826, 789, 744, $698 .{ }^{1} \mathrm{H}-\mathrm{NMR}\left(\mathrm{CDCl}_{3}, 400 \mathrm{MHz}\right)$ $\delta: 1.09\left(\mathrm{~s}, 6 \mathrm{H}, \mathrm{CH}_{3}\right), 1.22\left(\mathrm{~s}, 6 \mathrm{H}, \mathrm{CH}_{3}\right), 2.44-2.27\left(\mathrm{~m}, 8 \mathrm{H}, \mathrm{CH}_{2}\right), 5,63(\mathrm{~s}, 1 \mathrm{H}, \mathrm{CH}), 6.63(\mathrm{t}, 1 \mathrm{H}, \mathrm{J}=3.6 \mathrm{~Hz}$, $\mathrm{CH}), 6.86(\mathrm{dd}, 1 \mathrm{H}, \mathrm{J}=8.8 \mathrm{~Hz}, \mathrm{~J}=3.6 \mathrm{~Hz}, \mathrm{CH}), 7.1(\mathrm{~d}, 1 \mathrm{H}, \mathrm{J}=4.8 \mathrm{~Hz}, \mathrm{CH}), 12.31$ (s, $1 \mathrm{H}, \mathrm{NH}) .{ }^{13} \mathrm{C}-\mathrm{NMR}$ $\left(\mathrm{CDCl}_{3}, 400 \mathrm{MHz}\right) \delta$ : 189.89, 189.47, 143.69, 126.34, 124.53, 123.47, 115.95, 47.01, 46.24, 31.16, 30.40, 29.95, 26.75. HRMS (ESI $)$ : calcd. for $\mathrm{C}_{21} \mathrm{H}_{25} \mathrm{NO}_{2} \mathrm{~S}$ calcd. $378.1503[\mathrm{M}+\mathrm{Na}]^{+}$; found 378.1497 $[\mathrm{M}+\mathrm{Na}]^{+}$. 


\section{B. 2. 3,3,6,6-Tetramethyl-9-(pyridin-4-yl)-3,4,6,7,9,10-hexahydroacridine-1,8-(2H,5H)- dione (3b)}

White solid, yield: $86 \%$, m.p.:240-242 ${ }^{\circ} \mathrm{C}$ (Lit m.p.:245) [30-31], FT-IR $\left(v_{\max } / \mathrm{cm}^{-1}, \mathrm{KBr}\right): 2957,2883$, $1620,1586,1497,1410,1362,1260,1167,1141,1038,831,723 .{ }^{1} \mathrm{H}-\mathrm{NMR}{ }^{[32]}\left(\mathrm{CDCl}_{3}, 400 \mathrm{MHz}\right) \delta: 1.21$ (s, 6H, $\left.\mathrm{CH}_{3}\right), 1.20$ (s, 6H, CH 3 ), 2.37 (s, 4H, $\left.\mathrm{CH}_{2}\right), 2.39$ (s, 4H, $\left.\mathrm{CH}_{2}\right), 5.44$ (s, 1H, $\left.\mathrm{NH}\right), 6.99$ (dd, $2 \mathrm{H}$, $\mathrm{J}=3.2, \mathrm{~J}=1.2 \mathrm{~Hz}, \mathrm{CH}), 8.46(\mathrm{dd}, 2 \mathrm{H}, \mathrm{J}=6 \mathrm{~Hz}, \mathrm{~J}=1.2 \mathrm{~Hz}, \mathrm{CH}), 11.96$ (s, 1H, NH). HRMS (ESI ${ }^{+}$): calcd. for $\mathrm{C}_{22} \mathrm{H}_{26} \mathrm{~N}_{2} \mathrm{O}_{2}$ calcd. $373.1892[\mathrm{M}+\mathrm{Na}]^{+}$; found $373.1883[\mathrm{M}+\mathrm{Na}]^{+}$.

\section{B. 3. 9-(9-Ethyl-9H-carbazol-3-yl)-3,3,6,6-tetramethyl-3,4,6,7,9,10-hexahydroacridine- 1,8-(2H,5H)-dione (3c)}

Orange solid, yield: $94 \%$, m.p.: $192-195{ }^{\circ} \mathrm{C}$; (Lit m.p.:192-193 ${ }^{\circ} \mathrm{C}$ [32]), FT-IR ( $\left.v_{\max } / \mathrm{cm}^{-1}, \mathrm{KBr}\right): 2961$, 1681, 1590, 1463, 1446, 1349, 1290, 1232, 1147, 1065, 901, 828, 806, 749, 736. ${ }^{1} \mathrm{H}-\mathrm{NMR}\left(\mathrm{CDCl}_{3}, 400\right.$ $\mathrm{MHz}) \delta$ : $1.14\left(\mathrm{~s}, 12 \mathrm{H}, \mathrm{CH}_{3}\right), 1.41\left(\mathrm{t}, 3 \mathrm{H}, \mathbf{J}=7.1 \mathrm{~Hz}, \mathrm{~N}-\mathrm{CH}_{2}-\mathrm{CH}_{3}\right), 2.54-2.26\left(\mathrm{~m}, 8 \mathrm{H}, \mathrm{CH}_{2}\right), 4.32(\mathrm{q}, 2 \mathrm{H}$, $\left.\mathrm{J}=7.2 \mathrm{~Hz}, \mathrm{~N}-\underline{\mathrm{CH}}_{2}\right), 5.75(\mathrm{~s}, 1 \mathrm{H}, \mathrm{CH}), 7.44-7.14(\mathrm{~m}, 5 \mathrm{H}, \mathrm{ArH}), 7.82(\mathrm{bs}, 1 \mathrm{H}, \mathrm{CH}), 7.92(\mathrm{~d}, 1 \mathrm{H}, \mathrm{J}=7.6 \mathrm{~Hz}$, $\mathrm{CH}), 12.02(\mathrm{~s}, 1 \mathrm{H}, \mathrm{NH}) .{ }^{13} \mathrm{C}-\mathrm{NMR}\left(\mathrm{CDCl}_{3}, 400 \mathrm{MHz}\right) \delta: 190.41,189.50,143.55,140.66,128.48$, $128.19,122.85,122.82,120.80,120.30,118,51,116.21,109.15,108.70,108.43,108.14,47.18,37.90$, 32.66, 31.44, 27.30, 13.88. HRMS (ESI ${ }^{+}$): calcd. for $\mathrm{C}_{31} \mathrm{H}_{34} \mathrm{~N}_{2} \mathrm{O}_{2}$ calcd. $489.2518[\mathrm{M}+\mathrm{Na}]^{+}$; found $489.2510[\mathrm{M}+\mathrm{Na}]^{+}$.

\section{B. 4. 9-(1,5-Dimethyl-3-oxo-2-phenyl-2,3-dihydro-1H-pyrazol-4-yl)-3,3,6,6-tetramethyl- $3,4,6,7,9,10$ hexahydroacridine-1,8- $(2 \mathrm{H}, 5 \mathrm{H})$-dione $(3 \mathrm{~d})$}

White solid, yield: $91 \%$, m.p.: $163-164^{\circ} \mathrm{C}$, FT-IR $\left(v_{\max } / \mathrm{cm}^{-1}, \mathrm{KBr}\right): 3208,2943,1717,1629,1609,1592$, 1494, 1378, 1335, 1285, 1226, 1164, 1140, 1065, 971, 945, 869, 761. ${ }^{1} \mathrm{H}-\mathrm{NMR}\left(\mathrm{CDCl}_{3}, 400 \mathrm{MHz}\right) \delta$ : 1.07-0.90 (m, 12H, $\left.\mathrm{CH}_{3}\right), 2.03-2.00\left(\mathrm{~m}, 3 \mathrm{H}, \mathrm{CH}_{3}\right), 2.47-2.22\left(\mathrm{~m}, 8 \mathrm{H}, \mathrm{CH}_{2}\right), 3.09\left(\mathrm{~s}, 3 \mathrm{H}, \mathrm{N}-\mathrm{CH}_{3}\right), 4.58$ (s, $1 \mathrm{H}, \mathrm{CH}), 7.28-7.24(\mathrm{~m}, 3 \mathrm{H}, \mathrm{CH}), 7.41-7.38(\mathrm{~m}, 2 \mathrm{H}, \mathrm{CH}), 9.72(\mathrm{~s}, 1 \mathrm{H}, \mathrm{NH}) .{ }^{13} \mathrm{C}-\mathrm{NMR}\left(\mathrm{CDCl}_{3}, 400\right.$ MHz) $\delta: 205.53$, 197.38, 167.32, 165.48, 153.81, 133.94, 129.16, 127.30, 124.94, 108.96, 108.29, 98.46, 58.73, 53.83, 51.00, 49.28, 43.02, 35.12, 32.96, 32.31, 32.28, 29.43, 26.81, 26.00, 20.35, 11.12. HRMS $\left(\mathrm{ESI}^{+}\right.$): calcd. for $\mathrm{C}_{28} \mathrm{H}_{33} \mathrm{~N}_{3} \mathrm{O}_{3}$ calcd. $482.2419[\mathrm{M}+\mathrm{Na}]^{+}$; found $481.2422[\mathrm{M}+\mathrm{Na}]^{+}$.

\section{B. 5. 3,3,6,6-Tetramethyl-9-(5-methylfuran-2-yl)-3,4,6,7,9,10-hexahydroacridine-1,8- $(2 \mathrm{H}, 5 \mathrm{H})$-dione $(3 \mathrm{e})$}

Yellowish solid, yield: $95 \%$, m.p.: 146-148 ${ }^{\circ} \mathrm{C}$, FT-IR ( $\left.v_{\max } / \mathrm{cm}^{-1}, \mathrm{KBr}\right): 2963,2888,2636,1600,1447$, $1423,1378,1312,1252,1219,1168,1149,1049,1019,866,778 .{ }^{1} \mathrm{H}-\mathrm{NMR}\left(\mathrm{CDCl}_{3}, 400 \mathrm{MHz}\right) \delta: 1.07$ $\left(\mathrm{s}, 12 \mathrm{H}, \mathrm{CH}_{3}\right), 2.17\left(\mathrm{~s}, 3 \mathrm{H}, \mathrm{CH}_{3}\right), 2.43-2.34\left(\mathrm{~m}, 8 \mathrm{H}, \mathrm{CH}_{2}\right), 5.35(\mathrm{~s}, 1 \mathrm{H}, \mathrm{CH}), 5.80(\mathrm{dd}, 1 \mathrm{H}, \mathrm{J}=4.6 \mathrm{~Hz}$, $\mathrm{J}=1.2 \mathrm{~Hz}, \mathrm{CH}), 5.84(\mathrm{dd}, 1 \mathrm{H}, \mathrm{J}=4.1 \mathrm{~Hz}, \mathrm{~J}=2.0 \mathrm{~Hz}, \mathrm{CH}), 12.20(\mathrm{~s}, 1 \mathrm{H}, \mathrm{NH}) .{ }^{13} \mathrm{C}-\mathrm{NMR}\left(\mathrm{CDCl}_{3}, 400 \mathrm{MHz}\right)$ $\delta: 189.35,150.30,149.47,114.18,106.90,105.87,53.61,46.88,46.20,31.37,29.18,13.45$. HRMS $\left(\mathrm{ESI}^{+}\right)$: calcd. for $\mathrm{C}_{22} \mathrm{H}_{27} \mathrm{NO}_{3}$ calcd. $376.1888[\mathrm{M}+\mathrm{Na}]^{+}$; found $376.1890[\mathrm{M}+\mathrm{Na}]^{+}$.

\section{B. 6. 9-(Ferrocene-2-yl)-3,3,6,6-tetramethyl-3,4,6,7,9,10-hexahydroacridine-1,8-(2H,5H)- dione (3f)}

Soil solid, yield: $98 \%$, m.p.: $166^{\circ} \mathrm{C}$ (decomp.), FT-IR ( $\left.v_{\max } / \mathrm{cm}^{-1}, \mathrm{KBr}\right): 3675,2971,2901,1590,1450$, $1375,1307,1260,1240,1167,1151,1066,1074,1056,920,879,836,811,755 .{ }^{1} \mathrm{H}-\mathrm{NMR}\left(\mathrm{CDCl}_{3}, 400\right.$ $\mathrm{MHz}) \delta: 1.08\left(\mathrm{~s}, 6 \mathrm{H}, \mathrm{CH}_{3}\right), 1.21\left(\mathrm{~s}, 6 \mathrm{H}, \mathrm{CH}_{3}\right), 2.43-2.22\left(\mathrm{~m}, 8 \mathrm{H}, \mathrm{CH}_{2}\right), 4.01(\mathrm{~s}, 5 \mathrm{H}, \mathrm{CH}), 4.12(\mathrm{~s}, 4 \mathrm{H}$, $\mathrm{CH}), 5.73(\mathrm{~s}, 1 \mathrm{H}, \mathrm{CH}), 12.01(\mathrm{~s}, 1 \mathrm{H}, \mathrm{NH}) .{ }^{13} \mathrm{C}-\mathrm{NMR}\left(\mathrm{CDCl}_{3}, 400 \mathrm{MHz}\right) \delta: 198.12,149.51,116.66$, 77.30, 76.99, 76.68, 68.97, 68.53, 66.95, 46.87, 46.18, 31.18, 29.91, 29.56, 26.57. HRMS (ESI ${ }^{+}$): calcd. for $\mathrm{C}_{27} \mathrm{H}_{31} \mathrm{FeNO}_{2}$ calcd. $480.1601[\mathrm{M}+\mathrm{Na}]^{+}$; found $480.1620[\mathrm{M}+\mathrm{Na}]^{+}$. 


\section{RESULTS AND DISCUSSION}

Structures containing 1,4-DHP as a parent core demonstrate various biological activities besides being used as drugs. The most common route for the synthesis of 1,4-DHP derivatives is the condensation reactions of aromatic aldehydes with 1,3-dicarbonyl compounds. Accordingly, several studies have revealed the derivatization of these compounds and the development of synthetic methods in recent years. Among them, ultrasound-assisted synthesis has been found to be more effective. In this direction, we used this favorable method for the synthesis of 1,4-DHP derivatives containing various heteroaromatic groups that have the potential to exhibit biological activity [33, 34].

In order to optimize the various reaction conditions, such as the effect of solvents, temperature, and time, the reaction of dimedon (1a), 2-thiophene aldehyde (2a), and ammonium acetate were selected as the template (Table 1). According to these data, preliminary experiments were carried out in various solvents such as water, ethanol, and ethanol:water. The reaction temperature was hold in between 70 $100^{\circ} \mathrm{C}$ and heating conditions ranged in a duration of 60 minutes. As the best results have been obtained by carrying out the reaction with dimedone (2 eq), aldehydes $\mathbf{2 a - f}(1 \mathrm{eq})$ and ammonium acetate (1.5 eq) in water at $70{ }^{\circ} \mathrm{C}$ with the ultrasound irridation.

Table 1. Optimization conditions for the synthesis of 3,3,6,6-tetramethyl-9-(thiophen-2-yl)-3,4,6,7,9,10hexahydroacridine $1,8(2 \mathrm{H}, 5 \mathrm{H})$-dione $(3 \mathrm{a})$

\begin{tabular}{lccc}
\hline Solvent & Temperature $\left({ }^{\circ} \mathrm{C}\right)$ & Time $(h)$ & Yield (\%) \\
\hline Solvent free & 70 & 8 & Decomp. \\
\cline { 2 - 4 } & 100 & 5 & Decomp. \\
\hline EtOH & Reflux & 5 & 78 \\
\hline $\mathbf{H}_{2} \mathbf{O}$ & Reflux & 4 & 89 \\
\cline { 2 - 4 } & 70 & 1 & 97 \\
\hline EtOH:H & & & \\
\hline
\end{tabular}

Various synthetic methods have been developed and reported in the literature. The recap of the synthetic procedures for this compound has been shown in Table 2 . It has been obviously seen that water and $\mathrm{EtOH}$ have been preferred as the best solvent and the reaction temperature has been ranging from 60$100{ }^{\circ} \mathrm{C}$.

After optimization of the reaction conditions, we evaluated the scope and generality of the corresponding process by the reaction of a variety of substituted heteroaryl aldehydes (2b-f), dimedone (1) and ammonium acetate in water by using ultrasound irradiation to obtain 1,4-DHP derivatives (3b-f). It was determined that aldehydes were consumed completely after 1 hour when the monitored by thin layer chromatography (TLC) using hexane/ethyl acetate (4:1). For this purpose, 4-pyridine-carboxaldehyde (2b), 9-ethyl-9H-carbazole-2-carbaldehyde (2c), 2,3-dimethyl-5-oxo-1-phenyl-3-pyrazoline-4carboxaldehyde (2d), 5-methylfuran-2-carboxaldehyde (2e) and ferrocenecarboxaldehyde (2f) were treated with the mentioned conditions above. The reaction of $\mathbf{2 b}$ and $\mathbf{2 c}$ with dimedon was reported by literature [30-33] afforded $\mathbf{3 b}$ and $\mathbf{3 c} 83 \%$ and $87 \%$ respectively. We synthesized $\mathbf{3 b}$ and biologically active $3 \mathbf{c}$ compounds with higher yields in milder conditions and shorter times. Heteroaryl aldehydes showed good conversion with $>85 \%$ yield. 
Table 2. Condensation reactions of dimedone (1a) with thiophene aldehyde (2a).

\begin{tabular}{ccccccc} 
Catalyst & Solvent & $\begin{array}{c}\text { Temperature/ } \\
\left({ }^{\circ} \mathrm{C}\right)\end{array}$ & $\begin{array}{c}\text { Time } \\
(h)\end{array}$ & $\begin{array}{c}\text { Yield } \\
(\%)\end{array}$ & References \\
\hline Fe/M.S & EtOH & Reflux & 14 & $\begin{array}{c}\text { Compl. } \\
\text { Mix. }\end{array}$ & [1] \\
1,10-PHTNM & Water & 80 & 1 & $\mathbf{7 1}$ & [29] \\
Sitric acid & $\begin{array}{c}70^{\circ} \mathrm{C} ; 1 \mathrm{~h} \\
\text { EtOH }\end{array}$ & $\begin{array}{c}\text { Reflux } \\
\text { Solvent } \\
\text { free }\end{array}$ & 70 & 1 & $\mathbf{8 2}$ & [18] \\
No catalyst & Water & $\mathbf{7 0}$ & $\mathbf{1}$ & $\mathbf{9 7}$ & [17] \\
\hline
\end{tabular}

One of the best feature of this work is the simplicity of product isolation. Namely, filtration, water washing, and then drying have been found adequate. After recrystallization with ethanol, the pure product has been afforded.

The structure of model compound 3a was determined by FTIR, ${ }^{1} \mathrm{H}$ NMR and ${ }^{13} \mathrm{C}$ NMR spectra (Fig. 2). The FTIR spectrum showed characteristic absorption band at $3746 \mathrm{~cm}^{-1}$ for the NH group, the carbonyl groups were observed at $1631 \mathrm{~cm}^{-1} .{ }^{1} \mathrm{H}$ NMR spectrum of 3a remarked a singlet at $5.6 \mathrm{ppm}$ for aliphatic $\mathrm{CH}$ while NH group was observed chemical shift at $12.3 \mathrm{ppm} .{ }^{13} \mathrm{C}$ NMR of this compound showed two characteristic peaks at 189.5 and 189.9 ppm for carbonyl groups.

a.

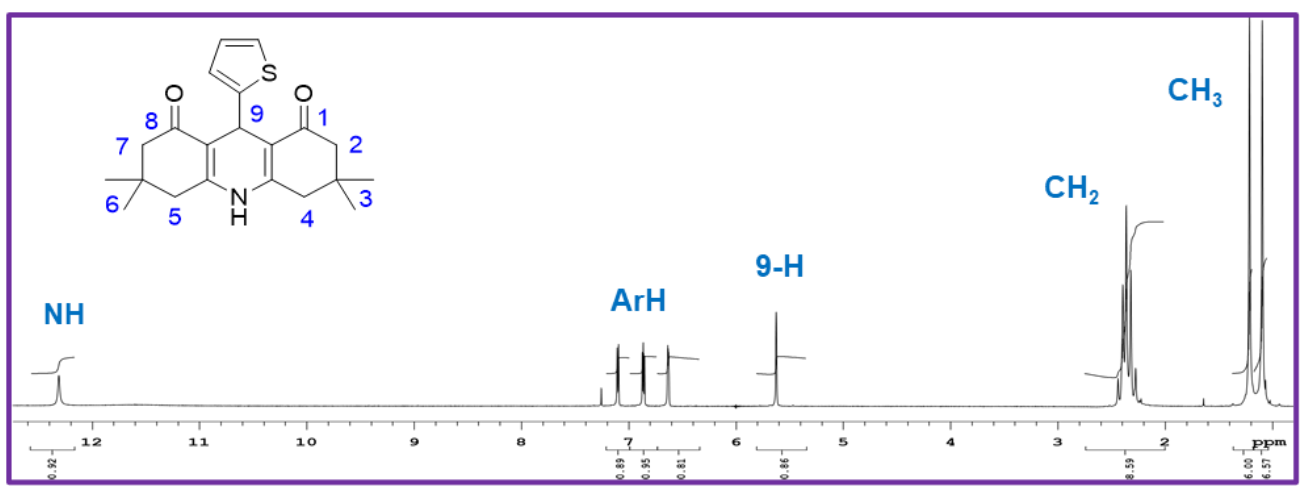


b.

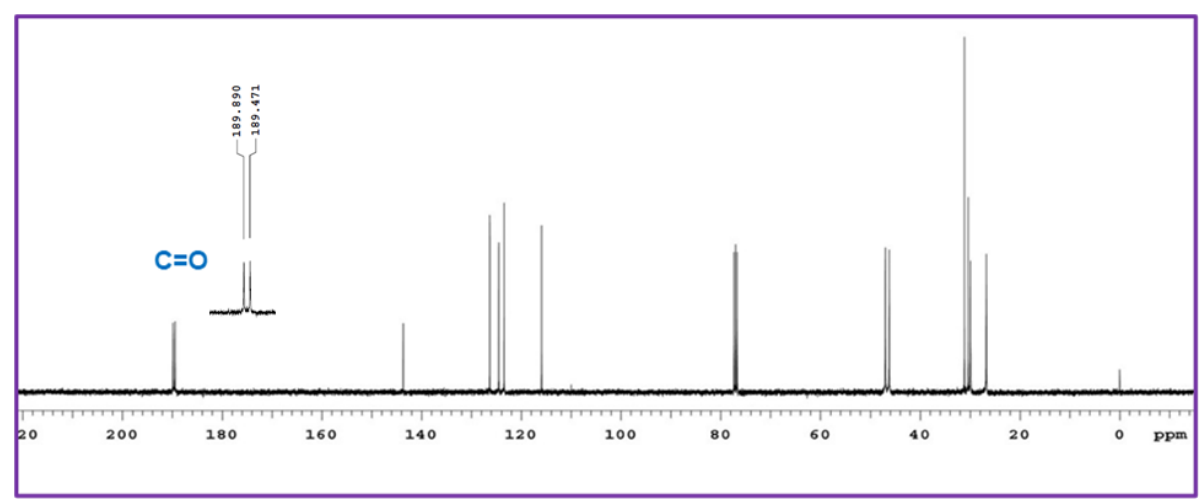

Figure 2. ${ }^{1} \mathrm{H} N M R(\boldsymbol{a})$ and ${ }^{13} \mathrm{C}$ NMR $(\boldsymbol{b})$ spectrum of 3,3,6,6-tetramethyl-9-(thiophen-2-yl)-3,4,6,7,9,10hexahydroacridine $1,8(2 H, 5 H)$-dione $(3 a)$

As indicated in Table 3, best results have been achieved by one-pot multicomponent reactions with other aldehydes (2d-f). Envisaged reactions proceeded under aqueous conditions to produce the corresponding 1,4-dihydropyridine derivatives (3d-f) with excellent yields.

Table 3. The condensation reactions of dimedone (1a) with heteroaromatic aldehydes $(\mathbf{2} \boldsymbol{b}-\boldsymbol{f})$.

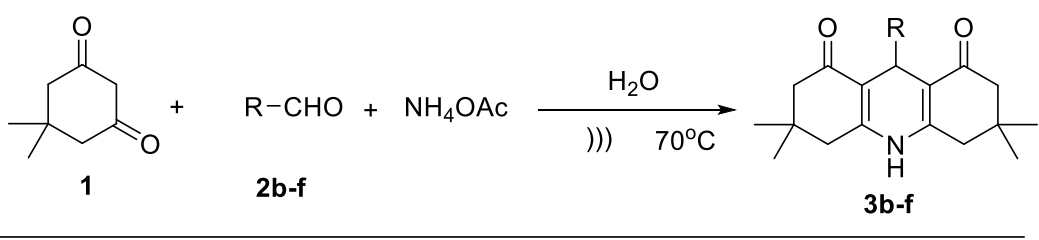<smiles>CC1(C)CC(=O)C2=C(C1)NC1=C(C(=O)CC(C)(C)C1)C2c1ccncc1</smiles>

$3 b \quad(86 \%)$<smiles>CCn1c2ccccc2c2ccc(C3C4=C(CC(C)(C)C4)NC4CC(C)(C)CC(=O)C43)cc21</smiles>

3c $(94 \%)$<smiles>Cc1c(C2C3=C(CC(C)(C)CC3=O)NC3=C2C(=O)CC(C)(C)C3)c(=O)n(-c2ccccc2)n1C</smiles>

$3 d \quad(91 \%)$<smiles>Cc1ccc(C2C3=C(CC(C)(C)CC3=O)NC3=C2C(=O)CC(C)(C)C3)o1</smiles>

3e $(95 \%)$<smiles>CC1(C)CC(=O)C2=C(C1)NC1=C(C(=O)CC(C)(C)C1)C2c1ccc(Oc2ccccc2)cc1</smiles>

3f $\quad(98 \%)$

The structures of synthesized compounds were confirmed on the basis of spectroscopic data. In the FTIR spectrum, the appearance of bands at around $1650-1680 \mathrm{~cm}^{-1}$ for $\mathrm{C}=\mathrm{O}$ and $3330-3350 \mathrm{~cm}^{-1}$ for $\mathrm{NH}$ has been considered as a sign of such functional groups. In the ${ }^{1} \mathrm{H} N \mathrm{NR}$, the appearance of the signal at 
$5.8 \delta$ referring to methine proton and $12.3 \delta$ referring to $\mathrm{NH}$ has supported the formation of target products $(\mathbf{3 b}-\mathbf{f})$.

Two equivalents of dimedone (1) and an equivalant of aldehydes (2a-f) were used together with 1.5 equivalents of ammonium acetate. The reactions were monitored by TLC. The proposed mechanism of these reactions is shown in Fig. 3. The hexahydroacridine 1,8-(2H,5H)-dione derivatives (3a-f) are probably formed by the commonly accepted route [26].

According to this mechanism, 2-arylidene-5,5-dimethylcyclohexane-1,3-dione (B) intermediate product is formed through the interaction of the dimedone (1) and heteroaromatic aldehydes (2a-f). Another molecule of dimedone (1) was condensed with ammonium acetate to afford enaminone (A). Then, addition and followed cyclization reactions of $\mathbf{A}$ and $\mathbf{B}$ compounds to give the desired products (3a-f).

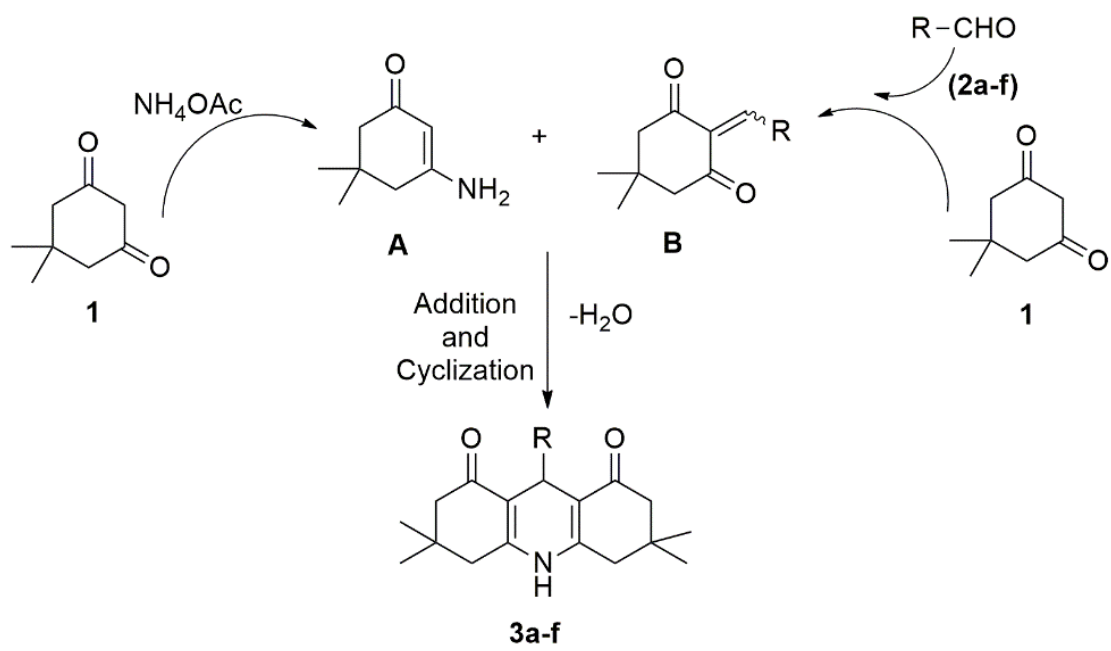

Figure 3. The proposed mechanism for the formation of hexahydroacridine 1,8-dione derivatives.

\section{CONCLUSION}

In this study, herein we report a simple and economically viable one-pot synthesis method of potential biological active 9-heteroaryl-substituted-acridinediones (3a-f) by the reaction of dimedone (1) with corresponding heteroaromatic aldehydes (2a-f) in excellent yields (86-98\%). The advantages of this study is the utilization of inexpensive reagents, use of green solvent, and easy work-up procedure which require no column chromatography for the purification and also the absence of toxic effluents. All the synthesized compounds were characterized by FTIR, ${ }^{1} \mathrm{H}$ and ${ }^{13} \mathrm{C}$ NMR, and LC-MS TOF analyses.

\section{REFERENCES}

[1] Á. Magyar and Z. Hell, "An efficient one-pot four-component synthesis of 9-aryl hexahydroacridine-1,8-dione derivatives in the presence of a molecular sieves supported iron catalyst," Catalysis Letters, vol. 149, no. 9, pp. 2528-2534, 2019.

[2] A. Velena, N. Zarkovic, K. Gall Troselj, E. Bisenieks, A. Krauze, J. Poikans, et al., "1,4dihydropyridine derivatives: dihydronicotinamide analogues-model compounds targeting oxidative stress," Oxidative medicine and cellular longevity, vol. 2016, pp. 35, 2016.

[3] D. J. Triggle, "Calcium channel antagonists: clinical uses - past, present and future," Biochemical pharmacology, vol. 74, no.1, pp. 1-9, 2007. 
[4] R. Mannhold, B. Jablonka, W. Voigt, K. Schoenafinger, E. Schraven, "Calcium-and calmodulinantagonism of elnadipine derivatives: comparative SAR," European journal of medicinal chemistry, vol. 27, no. 3, pp. 229-235, 1992.

[5] N. Edraki, A. R. Mehdipour, M. Khoshneviszadeh, R. Miri, "Dihydropyridines: evaluation of their current and future pharmacological applications," Drug Discovery Today, vol. 14, no. 22, pp. 10581066, 2009.

[6] A. Shafiee, R. Miri, A. Dehpour, F. Soleymani, "Synthesis and calciumchannel antagonist activity of Nifedipine analogues containing nitroimidazolyl substituent in guineapig ileal smooth muscle," Pharmacy and Pharmacology Communications, vol. 2, no. 11, pp. 541-543, 1996.

[7] F. Pourmorad, F. Hadizadeh, A.S hafiee, "Synthesis and calcium channel antagonist activity of 4imidazolyl1,4dihydropyridines," Pharmacy and Pharmacology Communications, vol. 3, no.4, pp.165$168,1997$.

[8] I. Antonini, P. Polucci, A. Magnano, S. Martelli, "Synthesis, antitumor cytotoxicity, and DNAbinding of novel N-5,2-di( $\omega$-aminoalkyl)-2,6-dihydropyrazolo[3,4,5-kl]acridine-5-carboxamides," Journal of medicinal chemistry, vol 44. no. 20, pp. 3329-3333, 2001.

[9] A. Albert, "The acridines: their preparation, physical, chemical, and biological properties and uses," Edward Arnold, London, 1966.

[10] P. Murugan, P. Shanmugasundaram, V. Ramakrishnan, B. Venkatachalapathy, N. Srividya, P. Ramamurthy, et al. "Synthesis and laser properties of 9-alkyl-3,3,6,6-tetramethyl-1,2,3,4,5,6,7,8,9,10decahydroacridine-1,8-dione derivatives," Journal of the Chemical Society, Perkin Transactions 2, vol. 4, pp. 999-1004, 1998.

[11] P. Shanmugasundaram, P. Murugan, V.T. Ramakrishnan, N. Srividya, P. Ramamurthy, "Synthesis of acridinedione derivatives as laser dyes," Heteroatom Chemistry, vol.7, no. 1, pp. 17-22, 1996.

[12] R. Popielarz, S. Hu, D. Neckers, "Applicability of decahydroacridine-1,8-dione derivatives as fluorescent probes for monitoring of polymerization processes," Journal of Photochemistry and Photobiology A: Chemistry, vol.111, no. 1, pp. 79-83, 1997.

[13] A. Papagni, P. Del Buttero, M. Moret, A. Sassella, L. Miozzo, G. Ridolfi, "Synthesis and properties of some derivatives of 1,2,3,4-tetrafluoroacridine for solid state emitting systems," Chemistry of materials, vol. 15, no. 26, pp. 5010-5018, 2003.

[14] G. Swarnalatha, "1,4-Dihydropyridines: a multifunctional molecule-a review," Int J Chem Tech Res., vol. 3, pp. 75-89, 2011.

[15] D. D. Pham, N.T. Le, G. Vo-Thanh, "Fast and efficient Hantzsch synthesis using acid-activated and cation-exchanged montmorillonite catalysts under solvent-free microwave irradiation conditions," Chemistry Select, vol. 2, no. 36, pp. 12041-12045, 2017.

[16] N. Madankumar, K. Pitchumani, " $\beta$-Cyclodextrin monosulphonic acid promoted multicomponent synthesis of 1,8 dioxodecahydroacridines in water," Chemistry Select, vol. 3, no. 39, pp.10886-10891, 2018.

[17] S. Abdolmohammadi, S. Dahi-Azar, M. Mohammadnejad, A. Hosseinian, "A simple and efficient synthesis of 4-arylacridinediones and 6-aryldiindeno[1,2-b:2,-e]pyridinediones using $\mathrm{CuI}$ nanoparticles 
as catalyst under solvent-free conditions," Combinatorial Chemistry \& High Throughput Screening, vol. 20, no. 9, pp.773-780, 2017.

[18] M. Patil, S. Karhale, A. Kudale, A. Kumbhar, S. More, V. Helavi, "Green protocol for the synthesis of 1,8-dioxo-decahydroacridines by Hantzsch condensation using citric acid as organocatalyst," Current Science, vol. 116, no. 6, pp. 936, 2019.

[19] M. Faisal, S. Shahid, S. A. Ghumro, A. Saeed, F. A. Larik, Z. Shaheen, et al., "DABCO-PEG ionic liquid-based synthesis of acridine analogous and its inhibitory activity on alkaline phosphatase," Synthetic Communications, vol. 48. no. 4, pp. 462-472, 2018.

[20] M. Kangani, N. Hazeri, M-T. Maghsoodlou, "Cobalt(II)nitrate hexahydrate, as an efficient catalyst for the synthesis of highly substituted piperidines and 1,8-dioxodecahydroacridine derivatives," Indian Journal of Chemistry-Section B Organic and Medicinal Chemistry, vol. 56, no. 6, pp. 663-669, 2017.

[21] R. Kardooni, A. R. Kiasat, H. Motamedi, "Designing of a novel dual-function silica-iron oxide hybrid based nanocomposite, $\mathrm{Fe}_{3} \mathrm{O}_{4} @ \mathrm{SiO}_{2} \mathrm{PEG} / \mathrm{NH}_{2}$, and its application as an eco-catalyst for the solvent-free synthesis of polyhydroacridines and polyhydroquinolines," Journal of the Taiwan Institute of Chemical Engineer, vol. 81, pp. 373-382, 2017.

[22] Z. Zarei, B. Akhlaghinia, "Zn II doped and immobilized on functionalized magnetic hydrotalcite $\left(\mathrm{Fe}_{3} \mathrm{O}_{4} / \mathrm{HT}-\mathrm{SMTU}-\mathrm{ZnII}\right)$ : a novel, green and magnetically recyclable bifunctional nanocatalyst for the one-pot multi-component synthesis of acridinediones under solvent-free conditions," New Journal of Chemistry, vol. 41, no. 24, pp.15485-15500, 2017.

[23] S. Karhale, M. Patil, G. Rashinkar, V. Helavi, "Green and cost effective protocol for the synthesis of 1,8-dioxo-octahydroxanthenes and 1,8-dioxo-decahydroacridines by using sawdust sulphonic acid," Research on Chemical Intermediates, vol. 43, no. 12, pp. 7073-7086, 2017.

[24] G. Shirole, S. Bhalekar, S. Shelke, "N-Butylpyridinium heptachlorodialuminate: A convenient catalyst for the synthesis of acridine 1,8-diones derivatives by microwave assisted Hantzsch reaction," Indian Journal of Chemistry, vol 57B, pp.1430-1435, 2018.

[25] A. Djemoui, M. R. Ouahrani, A. Naouri, L. Souli, S-E Rahmani, L. M. Boualem, "Eco-friendly and highly efficient one-pot synthesis of symmetrical and unsymmetrical 1,4-dihydropyridine derivatives using triethylamine as catalyst in ethanol medium," Heterocyclic Letters, vol. 8, no. 2, pp. 455-467, 2018.

[26] P. N. Chavan, D. N. Pansare, R. N. Shelke, "Eco-friendly, ultrasound-assisted, and facile synthesis of one-pot multicomponent reaction of acridine $1,8(2 \mathrm{H}, 5 \mathrm{H})$ diones in an aqueous solvent," Journal of the Chinese Chemical Society, vol. 66, no. 8, p. 822-828, 2019.

[27] M. Nikpassand, L. Zare, M. Saberi, "Ultrasound-assisted L-proline catalyzed synthesis of novel derivatives of azo-linked dihydropyridines," Monatshefte für Chemie-Chemical Monthly, vol. 143, no. 2, pp. 289-293, 2012.

[28] A. Shockravi, M. Kamali, N. Sharifi, M. Nategholeslam, S. P. Moghanlo, "One-pot and solventfree synthesis of 1,4-dihydropyridines and 3,4-dihydropyrimidine-2-ones using new synthetic recyclable catalyst via Biginelli and Hantzsch reactions," Synthetic Communications, vol. 43, no. 11, pp. 1477$1483,2013$.

[29] M. Dashteh, S. Baghery, M. A. Zolfigol, Y. Bayat, A. Asgari, "1,10Phenanthrolin1ium trinitromethanide (1,10-PHTNM) as a nano molten salt catalyst with Yaromatic counter ion: Applications for synthesis of organic compounds," Chemistry Select, vol. 4, no. 1, pp. 337-346, 2019. 
[30] P. Das, A. Dutta, A. Bhaumik, C. Mukhopadhyay, "Heterogeneous ditopic $\mathrm{ZnFe}_{2} \mathrm{O}_{4}$ catalyzed synthesis of $4 \mathrm{H}$-pyrans: further conversion to 1,4-DHPs and report of functional group interconversion from amide to ester," Green Chemistry, vol. 16, no. 3, pp. 1426-1435, 2014.

[31] Z. Alirezvani, M. G. Dekamin, E. Valiey, "New hydrogen-bond-enriched 1,3,5-tris(2hydroxyethyl)isocyanurate covalently functionalized MCM-41: an efficient and recoverable hybrid catalyst for convenient synthesis of acridinedione derivatives," ACS omega, vol. 4, no. 24, pp. 2061820633, 2019.

[32] K. Venkatapathy, C. J. Magesh, G. Lavanya, P. T. Perumal, S. Prema, "Design, synthesis, molecular docking, and spectral studies of new class of carbazolyl polyhydroquinoline derivatives as promising antibacterial agents with noncytotoxicity towards human mononuclear cells from peripheral blood," Journal of Heterocyclic Chemistry, vol. 57, no. 4, pp. 1936-1955, 2020.

[33] A. Saini, S. Kumar, J. S. Sandhu, "Hantzsch reaction: Recent advances in Hantzsch 1,4dihydropyridines,"Journal of Scientific and Industrial Research, vol. 67,pp. 95-111, 2008.

[34] Y. Zhang, Z. Zhou, "Solvent-free one-pot synthesis of 1,8-dioxo-decahydroacridines by a $\left[\mathrm{Et}_{3} \mathrm{NH}\right]\left[\mathrm{HSO}_{4}\right]$ catalyzed multicomponent reaction," Polycyclic Aromatic Compounds, vol. 38, no. 4, pp. 329-337, 2018. 